DOI: $10.17516 / 1997-1370-0576$

УДК 902:378

\title{
Archaeological Science and Education in Siberian Universities at the Turn of the Epochs
}

\author{
Lyudmila Yu. Kitova* \\ Kemerovo State University \\ Kemerovo, Russian Federation
}

Received 18.01.2020, received in revised form 18.03.2020, accepted 20.05.2020

\begin{abstract}
This research is devoted to archaeological science and education in Siberia at the end of the $19^{\text {th }}$ century - the first third of the $20^{\text {th }}$ century. The purpose of the article is to analyse the development of Siberian archaeology at the turn of the epochs when highlevel professionals first appeared in the region running away from the Bolsheviks from the European part of Russia and evacuated by A.V. Kolchak from Kazan and Perm universities. The reasons for the intensification of archaeological activity in Siberia in 1918-1926 were identified recreating an integral picture of its development. Particular attention is paid to identifying the specifics of the process of training researchers of antiquities at Tomsk and Irkutsk universities. Tomsk University, on the initiative of Professor S.I. Rudenko and lecturer S.A. Teploukhov, provided individual training of paleoethnologists as part of the natural science cycle of disciplines, while Irkutsk University established the first archaeological school in Siberia. The modernisation of higher education in the first years of the Soviet power led to the destruction of emerging historical education at Siberian universities and to the termination of archaeologists' training as a result.
\end{abstract}

Keywords: archaeology, training of historians, Tomsk State University, Irkutsk State University, paleoethnological scientific school.

Research area: archaeology.

Citation: Kitova, L.Yu. (2020). Archaeological science and education in Siberian universities at the turn of the epochs. J. Sib. Fed. Univ. Humanit. Soc. Sci., 14(1), 137-147. DOI: 10.17516/1997-1370-0576.

(C) Siberian Federal University. All rights reserved

* Corresponding author E-mail address: lyudmila.kitova@mail.ru ORCID: 0000-0003-4769-9819 


\section{Introduction}

The centenary of the Great Russian Revolution and the intensity of the Orange revolutionary passions in the world suggest that researchers once again think about the results and lessons of revolutionary changes in different areas of society life and activities including such fields as science and education. Moreover, the contemporary modernisation of science and higher education in Russia included its participants in determining the prospects for this process, which are not possible without a retrospective analysis.

The initiator of the development of historiographic problems in Russian archaeology was Muscovite, a researcher at the Institute of Archaeology of the Russian Academy of Sciences A.A. Formozov (Formozov, 1961; Formozov, 1986; Formozov, 1995). Nevertheless, it was the representatives of the scientific school of Saint Petersburg who for the first time considered the issue of institutionalisation of archaeology in Russia deeply and in various aspects.

An important milestone in comprehending the development of Russian archaeology was the monograph by G.S. Lebedev (Lebedev, 1992), in which Russian science was considered in a wide range: from 1700 to 1917 against the background of world archaeology.

L.S. Klein was one of the first to analyse the stages of formation and the main directions of development of Soviet archaeology and determined the influence of Stalinism on it (Klein, 1993). He later created two fundamental works: one is devoted to the history of world archaeological thought (Klein, 2011), the other to the history of pre-revolutionary, Soviet and post-Soviet archaeology (Klein, 2014).

I.V. Tunkina studied the process of formation of the Russian science on the classic antiquities of the south of Russia in the $18^{\text {th }}$ - middle of the $19^{\text {th }}$ centuries (Tunkina, 2002).

The monograph by I.L. Tikhonov on the emergence and development of the archaeological science in Saint Petersburg University is especially interesting in terms of the topic of our research (Tikhonov, 2003).

Studying the history of archaeological thought in Russia at the end of the $19^{\text {th }}-$ the first third of the $20^{\text {th }}$ centuries, N.I. Platonova developed the author's concept of its development on the basis of two platforms: archaeology as a science of the humanities and archaeology as a natural history discipline, for which, in her opinion, there were two different systems of philosophical views on human nature and the history of mankind. Based on the analysis of the activities of two metropolitan archaeological centres, the researcher rightly debunked the myth of empiricism and methodological failure of Russian archaeology of the end of the $19^{\text {th }}$ the first third of the $20^{\text {th }}$ centuries (Platonova, 2010).

However, materials on the formation and development of Siberian archaeology are not presented in the works of Saint Petersburg researchers. This problem was solved by V.I. Matiushchenko in a two-volume monograph, which examines the history of archaeology of Siberia of the $18^{\text {th }}-20^{\text {th }}$ centuries (Matiushchenko, 2001). Using unpublished archival materials, we investigated unknown and debatable issues of the development of Siberian archaeology in 1920-1930 (Kitova, 2007). Nevertheless, the specificity of emerging and development of training researchers of antiquities at Tomsk and Irkutsk universities in the first quarter of the $20^{\text {th }}$ century were not revealed, which this article is devoted to.

\section{Research methods}

The article uses general historical methods:

- historical and comparative, to establish general and special features of the development of the teaching of archaeology in the European and Asian parts of Russia;

- problematic and chronological, according to which the recreation of events is carried out in chronological sequence;

- historical and systematic, which allowed to identify the reasons for the intensification of archaeological activity in Siberia in 1918-1926, to recreate a holistic picture of its development;

- historical and genetic, which made it possible to determine the organisational structure of historical education in national universities in the $19^{\text {th }}$ century and the dynamics of 
its transformation in the first quarter of the $20^{\text {th }}$ century.

The use of a comprehensive interdisciplinary approach for dealing with issues of interaction between scientists, society and the authorities made it possible to analyse the development of the organisational structure of Siberian archaeology in the context of wider historical transformations. To study archival materials we applied a comprehensive source study approach.

\section{The beginning \\ of teaching archaeology in Russia}

Archaeology is a young science, which started to develop in Russia in the second half of the $19^{\text {th }}$ century - beginning of the $20^{\text {th }}$ century. In the indicated period, material sources had been accumulated from the Palaeolithic to the Middle Ages; research methods were developed, first of all typological. Archaeologists began to classify complexes of artefacts, using the materials of the European part of the Russian Empire, the first archaeological cultures were identified and typological series of things were constructed in a relatively chronological sequence. State (Imperial Archaeological Commission) and public organisations (Russian Archaeological Society, Moscow Archaeological Society, etc.) were established to guide archaeological research. Periodicals dedicated to archaeological research began to appear and a circle of researchers was formed involved in solving a wide range of problems of prehistory, which had their followers. As a result, these researchers started teaching archaeology at universities.

According to the Charter of 1804, the Chair of the Theory of Fine Arts and Archaeology was established at the Department of Philosophy at Moscow University (Istoricheskii fakul'tet MGU, 2019), and in 1809 a course of lectures on archaeology and history of fine arts appeared in the curriculum of the Department (Arkheologiia, 2006: 9). However, archaeology was not taught as an independent discipline, and students were offered some general knowledge in the field of the humanities, primarily on the monuments of antiquity. With the establishment of the Division of History and Philology at the Department of Philosophy of Moscow State University in 1835, the number of disciplines in which information on ancient history and archaeology was used, started to increase gradually.

Classical (antique) archaeology in Russia passed the stage of its organisational development earlier than all other fields (Tunkina, 2002: 607-609), due to the interest in ancient antiquities in Europe, which also influenced the hobbies of the Russian nobility, and then the researchers of Greek and Roman artefacts. Slavic-Russian and primitive archaeology will be formed as independent fields later.

In 1884, the Chair for Geography and Ethnography, headed by D.N. Anuchin, was established at the Department of History and Philology of the University of Moscow, which began to function since 1850 . He would develop a course of lectures on prehistoric (primitive) archaeology, anthropology and ethnography. However, already in 1888 at the request of the scientific community of Moscow State University the Chair for Geography and Ethnography was transferred to the Natural Science Subdivision of the Department of Physics and Mathematics. The teaching of prehistoric archaeology was also transferred to the Department of Physics and Mathematics (Platonova, 2010: 147). It should be noted that in Russian science, not only geography belonged to the circle of natural science disciplines, but also ethnography, which for a long period was formed within the framework of geography.

At Saint Petersburg University from 18461848 the Department of History and Philology introduced original courses in archaeology, Greek and Roman antiquities, and in the 1870s certain information on archaeology was provided when giving lectures on Russian history. However, at the turn of the epochs, archaeology gained a stable position in the educational and scientific activities of the university (Tikhonov, 2003: 25, 43, 83).

Archaeological institutes also functioned in the capitals: Saint Petersburg (1878-1922) and Moscow (1907-1922) institutes, which initially trained specialists in reading ancient manuscripts, and not in the study of archaeological sites. The teaching of archaeology at 
Saint Petersburg Archaeological Institute was established only in 1891 (Tikhonov, 2003: 138).

It should be noted that the universities of the Russian Empire did not train specialists in archelogy, there were no independent departments of archaeology and specialisation in archaeology, as will be established in the Soviet period. However, traditionally those who wanted to be engaged in classical (antique) and Slavic-Russian archaeology studied at the historical and philological departments of universities.

The interest for primitive archaeology in Russia appeared much later than for classical and Slavic-Russian archaeology. Until the middle of the $19^{\text {th }}$ century the origin of man was considered in terms of biblical tradition. The early pages of the history of mankind were not associated with the natural historical process, and archaeological artefacts were not inscribed in the geological context. The interest for primitive ages appeared after striking discoveries of C. Darwin, who in his fundamental works On the Origin of Species (1859) and The Descent of Man, and Selection in Relation to Sex (1871) determined the interconnection of all forms of life, the unity of the human race and strongly argued the materialistic theory of the development of all living things. These discoveries influenced archaeology. The science of primitiveness was considered as a discipline of the natural science cycle, and of ancient man as a part of nature. Therefore, primitive (prehistoric) archaeology was also attractive for students of the natural science subdivisions of the departments of physics and mathematics at universities. Moreover, the paleo-ethnological field that dominates the scientific worldview of Russian researchers at the turn of the epochs considered primitive archaeology in close connection with ethnology, physical anthropology, geography and natural science.

\section{The results of the development of archaeology in Siberia at the turn of epochs}

Unsurprisingly Siberia at that time lagged behind the development of science in the capitals. The vast region did not have higher educational institutions where they could teach any disciplines about antiquities, respectively, there were not enough researchers involved in archaeological research. The main institutions around which local researchers could unite were museums. If at the beginning of the $19^{\text {th }}$ century there were a few museums, then after the initiation of economic development of Siberian lands in the post-reform period, the number of local museums increased significantly. Irkutsk, Krasnoyarsk and Minusinsk museums were especially noticeable for their archaeological activities. A significant contribution to the study of archaeological sites of the region was made by the Siberian departments of the Imperial Russian Geographical Society (Kitova, 2014b: 15-17). The Museum of Archaeology and Ethnography founded in 1882 at Siberian University in Tomsk played a special, consolidating role. Its founder, the trustee of the West Siberian Educational District, V.M. Florinsky, laid the foundations for collecting and cataloguing museum collections. The studies of Tomsk citizens - the first librarian of Siberian University S.K. Kuznetsov, the professor and zoologist N.F. Kashchenko, the anatomist and anthropologist S.M. Chugunov, as well as the public figure and official, deeply and seriously involved in science and a professional archaeologist and ethnographer later, A.V. Adrianov, were of great importance for the development of Siberian archaeology.

It is well known that the only Siberian University that has been operating since 1888 , at first there was only one department - the medical one, then the legal department was established in 1898, and only on July 1, 1917 it was decided to establish the Department of History and Philology and the Department of Physics and Mathematics with the Subdivision of Geology and Geography (Nature Sciences)', i.e. until mid-1917 there was no department where one could listen to lectures containing information on archaeology or ancient history.

Nevertheless, both doctors and lawyers of Tomsk University showed interest in historical research (Khaminov, 2011: 16). Moreover, teachers of the Medical Department seriously studied the issues of anthropology of the aborigines of Siberia. Using archaeological excavations, they needed to obtain bone materials of the ancient population living in

State Archive of Tomsk Oblast. F. 102. Op. 1. D. 820. L. 3. 
the region, but this does not mean that such branches of science as archaeology and anthropology were considered to be the humanities, as D.V. Khaminov points out (Khaminov, 2011: 17, 19). In our opinion, the researcher is modernising the understanding of the tasks and the subject of primitive archaeology by natural scientists of the Russian Empire. In contrast to classical and Slavic-Russian archaeology, the scientific community considered it at that time as part of natural history, and not the history of society.

Despite the lack of historical or paleoethnological education in Siberia before the First World War, a significant groundwork was performed in archaeological research. A corpus of material sources was formed, and just as in the European part of Russia, it could be used to characterise the ancient history of Siberia from the Palaeolithic to the Middle Ages. Although the discovery of the Palaeolithic sites did not occur as a result of a systematic search for the most ancient monuments left by primitive people, but in the course of construction works, though their study confirmed that human life was present in Siberia in ancient times. When excavating the sites, Siberian researchers used original methods that were ahead of time. For example, I.D. Chersky studied Irkutsk hospital site on the basis of an integrated approach in terms of archaeology, geology and palaeontology. N.F. Kashchenko investigated Tomsk site using advanced methods - the planigraphic method of excavation, the so-called method of opening wide areas that no one had used before. During the excavation, he applied a square grid in order to accurately fix all the artefacts. Long-term research of I.T. Savenkova on Afontovo Hill secured the first data on the resettlement of man in Siberia during the Upper Palaeolithic.

Especially large amount of archaeological materials was obtained on the sites of the Bronze and Iron Ages. The first cultural-chronological periodisation established by V.V. Radlov was introduced into scientific circulation, recreating the main stages in the development of cultures of Southern Siberia from the Bronze Age to the "Yenisei Kyrgyz" period (Radlov, 1989: 410-480). V.V. Radlov, I.P. Kuznetsov-Kras- noyarsky and D.A. Klements developed classifications of funerary sites of the Metal Age. A.V. Adrianov applied a scientific approach to fixing petroglyphs, a and new methods of copying petroglyphs.

However, there were gaps such as the lack of system in the study of archaeological sites, the lack of classification of complexes of artefacts in a relatively chronological sequence. Accordingly, no archaeological cultures were identified, as well as no training system for historians was developed. Thus, the process of development of archaeology as a science in Siberia at the end of the $19^{\text {th }}$ century - beginning of the $20^{\text {th }}$ century was not complete (Kitova, 2014a: 27-28). Moreover, before the First World War, in Siberia, there was a change of generations of researchers. In 1892, N.I. Vitkovsky and I.D. Chersky passed away, and V.V. Radlov and D.A. Klements moved to Saint Petersburg. In 1904, the director of the Minusinsk Museum N.M. Martyanov died, under whose leadership one of the best archaeological collections in Siberia was gathered. With the onset of the $20^{\text {th }}$ century, field archaeological surveys in Tomsk cease leading to the extinction of the university's archaeological museum. In 1914, I.T. Savenkov died. Such experts as I.D. Chersky, N.I. Vitkovsky, V.V. Radlov, D.A. Klements and I.T. Savenkov are not easy to replace. Of course, all these events resulted in the stagnation in the archaeological studies of the region. It should be noted that almost all researchers except V.V. Radlov had education in natural science.

\section{Archaeology in Siberian universities in 1918-1926}

After the revolution and during the outbreak of civil war, the conditions for the development of historical science and education in the country worsened. The Bolsheviks repressed those who did not approve of their actions in the centre of Russia, some scientists emigrated to other countries. Siberia was captured by the Czech and Slovak legion and the army of A.V. Kolchak. The intelligentsia was frightened by red terror, famine and devastation. Some scientists hid from all these adversities in Siberia, linking hopes for the revival 
of the country with the activities of A.V. Kolchak.

An unusual situation developed in the region: on the one hand, the Civil War erupted, and on the other, a university was established in Irkutsk in 1918. For the first time, there were high-class specialists at Tomsk and new Irkutsk universities (for example, the rector of Tomsk University in 1920-1921 was professor of classical studies B.L. Bogaevsky), who were mainly evacuated from Kazan and Perm universities, as well as those who fled from the Soviets from the European part of Russia. They began to deliver lectures on ancient history, archaeology, ethnology, primitive culture. Students began to participate in field archaeological research along with their teachers.

Obviously, if it was not for the civil war, so many professionals would not have come to Siberia voluntarily. However, we must give them their due, as the researchers who arrived, despite the hardships of life such as hunger, cold, illness, deficiency of the most necessary things, were passionate about their work. Apparently, it saved them, giving hope for the future.

In January 1919, the Institute for the Studies of Siberia was established in Tomsk, which, as conceived by its founders, was supposed to replace the Academy of Sciences. An archaeologist from Kazan University V.F. Smolin at its founding congress set out the principles for organising archaeological studies of Siberia. He believed that excavation could only be carried out on behalf of the state, for the purpose of which a special archaeological department should be established at the Institute for the Studies of Siberia, which would be engaged in the registration of ancientries, their protection, issuing permits for archaeological excavations, and compiling an archaeological map of the region. V.F. Smolin also suggested improving archaeological methods for studying ancient sites. He worked at the Department of History and Philology of Tomsk University for about two years, but managed to become an initiator of the establishment of Tomsk Regional Museum, Tomsk Provincial Archive and the service for the protection of monuments of art and ancientries in the Tomsk province. In 1920 V.F. Smolin together with I.M. Myagkov, a student of the Department of History and Philology of the University, performed excavations of the Tomsk burial ground ${ }^{2}$.

The palaeontologists S.I. Rudenko and S.A. Teploukhov, who arrived in 1919, specialists in natural science by education, taught at the Chair for Geography of the Natural Sciences Subdivision of the Physics and Mathematics Department of Tomsk University and were employees of the Institute for the Studies of Siberia. S.I. Rudenko first headed the Chair for Geography, and since 1920 he was elected the Dean of the Physics and Mathematics Department. S.I. Rudenko and S.A. Teploukhov, the first in Tomsk, gave lectures to students in geography, ethnography, anthropology and paleoethnology (ancient ethnology). Therefore, continuity with the previous system of training students in national universities was preserved, i.e. to study primitive archaeology in the framework of natural science disciplines. In 1920-1921 S.I. Rudenko and S.A. Teploukhov carried out active comprehensive research on anthropology, geography, ethnography, archaeology and travelled to the Minusinsk region to carry out excavations. Thus, S.A. Teploukhov during the first field season examined ten graves and two burial mounds, and fourteen burials in the summer of 1921. It is believed that he classified archaeological cultures of the Minusinsk region, which has retained its scientific significance until now, in later works (Teploukhov, 1927; Teploukhov, 1929). However, he identified the first five cultures in 1920-1921 in Tomsk and reflected this in his reports. Thus, in the excavation report for 1920, S.A. Teploukhov indicates that he examined three graves of the Afanasievo culture, one of Andronovo culture, six of the Karasuk culture, two mounds of the Minusinsk Tagar culture, which he initially considered the culture of classical Bronze $\mathrm{Age}^{3}$. In the report on the geological and anthropological expedition to the Yenisei province for 1921, the researcher

\footnotetext{
State Archive of Tomsk Oblast. F. R-815. Op. 1. D. 34. L. 23-25. F. R-26. Op. 1. D. 40. L. 34-44.

3 Handwritten archive of the Institute of Material Culture History. F. 2. Op. 1. 1921. D. 90.
} 
adds the fifth culture with the Iron Age mounds to the above mentioned cultures ${ }^{4}$.

The first students to participate in scientific research of S.I. Rudenko and S.A. Teploukhov were M.P. Gryaznov, E.R. Schneider, E.A. Gukovsky, Yu.M. Golubkova and A.N. Glukhov5 . A classroom for geography and anthropology studies was established at Tomsk University. Apparently, students did not specialise in primitive archaeology, anthropology or paleoethnology. For such innovations, serious financial and material resources, scientific staff and great organisational work were needed. Teachers worked with students individually. It was in 1920 when a student of the Natural Sciences Subdivision of the Department of Physics and Mathematics, in the future a famous Soviet archaeologist, M.P. Gryaznov was fascinated by archaeology for life.

Thus, using the example of S.A. Teploukhov, we can state that the researchers, in spite of life's difficulties and trials, achieved scientific success, were ready to continue to work in the field of Siberian science and higher education.

However, after the defeat of A.V. Kolchak's army, the power of the Soviets began to take hold in Siberia, and at the same time, education reform began at Tomsk and Irkutsk universities. Initially, all departments for the humanities (legal, historical and philological) were closed, and on their basis in 1921 the departments of social sciences were established. However, two departments of social sciences appeared to be too many for Siberia, and the one at Tomsk University was closed in 1922. The Institute for the Studies of Siberia was also closed in 1920.

The lack of funds led to a further search for reducing universities' financing. At universities, they began to compile lists of departments that did not have specific applied value. Among them, there was the Natural Sciences Subdivision of the Department of Physics and Mathematics at Tomsk University. Dean of the Department S.I. Rudenko decided not to wait for the end of the reform and in November

\footnotetext{
4 State Archive of Tomsk Oblast. F. R-815. Op. 1. D. 89. L. 61-65.

5 State Archive of Tomsk Oblast. F. 102. Op. 9. D. 560. L. 13.
}

1921 he moved to Petrograd ${ }^{6}$. Following him, S.A. Teploukhov leaves in the spring of 1922, and sometime later, students M.P. Gryaznov, E.R. Schneider and I.M. Myagkov wishing to continue their education.

After those events, there were no archaeologists or paleoethnologists left in Tomsk. There was no individual training, neither theoretical (lecturing) nor practical, i.e. participation in archaeological research. In 1919-1922 Tomsk University loses its position as emerging Centre of Siberian Archaeology. The restoration of historical education at the university would occur only in 1940, and the revival of archaeological research would be connected with the names of the archaeologist, professor K.E. Grinevich and philologist, professor A.P. Dulzon who were exiled to Tomsk during the Great Patriotic War.

At Irkutsk University, which opened in 1918, historical education existed for a longer period, and accordingly, there was more thorough training of researchers of antiquities.

During the Civil War many famous ethnologists, linguists, arrived in Irkutsk. In the 1920s the first Siberian archaeological school was formed there as well. It was founded by a paleoethnologist, an employee of the Museum of Anthropology and Ethnography (Kunstkamera) Bernhard Eduardovich Petri. In 1918, he headed the Chair for the History of Primitive Culture of the Department of History and Philology and established a paleo-ethnological centre in Irkutsk, which, in addition to the Department, consists of the Museum of Ethnography, the class of archaeology and ethnography of the indigenous peoples of Siberia, and the Student scientific club of ethnic studies.

This scientific school was distinguished by its own - paleoethnological - research methodology, excavation methodology, and organisation of fieldwork.

B.E. Petri was a versatile, serious scientist. He made a significant contribution to the archaeology of Siberia, explored various archaeological sites of the region and, first of all, the multi-layered Neolithic site of fishermen

\footnotetext{
6 Saint-Petersburg branch of the Archive of the Russian Academy of Sciences. F. 1004. Op. 1. D. 268. L. 1. D. 302. L. 3-4.
} 
of Ulan-Khad. The study of this settlement allowed the scientist to create a cultural-chronological periodisation of the Neolithic of the Baikal region, which at present has not lost its significance as a reference site for the periodisation of the ancient history of the region.

Moreover, Professor B.E. Petri developed and delivered lectures on the history of primitive culture, archaeology, ethnography, as well as special courses on archaeological exploration and excavation techniques, museum work, etc. ${ }^{7}$ He wrote guides for students on the Palaeolithic and the Neolithic periods of Siberia, which were the first publications on the declared topics and were a summary of the famous archaeological sites (Petri, 1923a; Petri, 1926).

Bernhard Petri developed his own system of training research staff. Students did not just attend his classes, but received personal tasks on archaeological field research, which they conducted on their own, then the results of the research were presented in the form of original reports at meetings of the student group or the club of the East Siberian Department of the Russian Geographical Society. This club also worked after the closure of the Department of Social Sciences in 1926 and celebrated its 10th anniversary with Irkutsk University in 1928 (Petri, 1928: 3). In order for students to correctly explore such an important type of archaeological sites as settlements and to collect as complete information about them as possible, B.E. Petri developed and published the "Programme for the Study of Encampments". Guided by the paleoethnological methodology, he insisted on a detailed physical and geographical characteristic of the area with a description of the surrounding mountains, rivers, lakes, insolation, the prevailing wind and traces of its activity. Students needed to collect all information about fish and hunting grounds, about swamps, about their location in relation to the settlement, about the possibility of catching fish with a net; and also discover places where the ancient inhabitants took water, stone, clay (Petri, 1923b). B.E. Petri believed that the study of a settlement in a natural context is of par-

\footnotetext{
Handwritten archive of the Institute of Material Culture History. F. 35. Op. 5. D. 294. L. 21.
}

amount importance for extracting information about the life of primitive people.

Such a training system paid off and gave an excellent result. B.E. Petri's school educated famous scientists, such as A.P. Okladnikov, M.M. Gerasimov, G.F. Debets, G.P. Sosnovsky, P.P. Khoroshikh, many museum workers and researchers of Siberia.

Despite the good student learning outcomes at Irkutsk University, the Department of Social Sciences was closed, as it happened to the Department in Tomsk. The system of reorganisation of higher education led to the outflow of professional personnel from Irkutsk. Students of B.E. Petri were enrolled for graduate studies in Moscow and Leningrad: G.P. Sosnovsky in 1926, G.F. Debets in 1927, M.M. Gerasimov in 1932, AP. Okladnikov in 1934. Bernhard Eduardovich himself also left his position at the University in 1926, and in 1937 he was repressed. After the departure of a number of researchers and repressions, no archaeologists, ethnographers, and museum workers remained in the city.

Therefore, the reform of higher education nullified training of students in the field of history and archaeology in Siberia. University historical education will return to Irkutsk, as well as to Tomsk, in 1940. But even after the end of World War II, archaeological science in Irkutsk will not be restored at the level of development of the 1920 s, it will take a longer period than in Tomsk (Kitova, 2014b: 88-92).

Unfortunately, the historical background for the development of archaeology in Siberia in the 1930s also did not contribute to any research. Local history movement in 1919-1929 was suppressed by the totalitarian state in the 1930s, museum workers and local historians were almost completely subjected to repression. Such a vast territory as Siberia before the establishment of the Siberian Branch of the USSR Academy of Sciences was studied in terms of archaeology pointwise, unevenly, mainly with the help of reconnaissance studies by small forces of individual local researchers, and more broadly and systematically by researchers from Moscow and Leningrad.

Departments of Archaeology in Siberia were established late. In the European part of 
the country they were established in 1936 - at Leningrad University, in 1939 - at Moscow University, while in Siberia the first department was opened at Kemerovo University in 1975.

\section{Conclusion}

Therefore, the formation period of Siberian archaeology was longer than in the European part of Russia, and ended in the 1920s, when a training system appeared at universities, and periodisation of sites and classification of archaeological cultures were created in Siberian archaeology. Before the emergence of higher historical education in Siberia, a complex of archaeological sources was accumulated and a network of local history museums was created, in which, as far as possible, collections of antiquities were stored, studied, and exhibited.

The opening of Department of History and Philology and Departments of Geography at Siberian universities, where anthropology, ethnology and paleoethnology were taught, did not guarantee the availability of teachers to train the students in peacetime. Let us recall for how long there were not enough materials and human resources for providing a full-fledged university education in Tomsk. However, the erupted political crisis and civil war forced many scientists and university professors from the European part of Russia to seek refuge in Siberia. The influx of high-level professionals made it possible to organise classes in archaeology, conduct archaeological and paleoethnological studies. The first graduates had a desire to continue to do research.

Nevertheless, the results of the modernisation of education and science in the early years of Soviet power show that the destruction of the old university training system led to the destruction of any historical education in Siberia for many years. In turn, this caused a significant lag in archaeological research of provincial universities from those located in the capital.

\section{References}

Arkheologiia: uchebnik [Archaeology: textbook] (2006). ed. by V.L. Ianina. Moscow, Izdatel'stvo Moskovskogo universiteta, $608 \mathrm{p}$.

Istoricheskii fakul'tet MGU. Istoriia fakul'teta [Faculty of History of Moscow State University. The history of the Faculty] (2019). Available at: http://www.hist.msu.ru/about/history/ (accessed 26 January 2019).

Kitova, L.Yu. (2007). Istoriia sibirskoi arkheologii (1920-1930-e gody): izuchenie pamiatnikov epokhi metalla [The history of Siberian archaeology (1920-1930s): the study of the Metal age sites]. Novosibirsk, Izdatel'stvo Instituta arkheologii i etnografii SO RAN. 272 p.

Kitova, L.Yu. (2014a). K voprosu o stanovlenii sibirskoi arkheologii i kriteriiakh periodizatsii ee istorii [Formation of Siberian archaeology and criteria for its history periodization]. In Vestnik Kemerovskogo gosudarstvennogo universiteta [Bulletin of Kemerovo State University], 3 (59), 2, 24-30. DOI: 10.21603/20788975-2014-3-24-30.

Kitova, L.Yu. (2014b). Istoriia arkheologii Sibiri: idei i issledovaniia (XVII v. - seredina XXv.) [The history of the archaeology of Siberia: ideas and research (XVII c. - the middle XX c.)]. Kemerovo, KemGU, $228 \mathrm{p}$.

Klein, L.S. (1993). Fenomen sovetskoi arkheologii [The phenomenon of Soviet archaeology]. Saint Petersburg, FARN, $128 \mathrm{p}$.

Klein, L.S. (2011). Istoriia arkheologicheskoi mysli v 2-kh tomakh [History of archaeological thought in 2 vols.]. Saint Petersburg, Izdatel'stvo S.-Peterburgskogo universiteta, 688 p., 624 p.

Klein, L.S. (2014). Istoriia rossiiskoi arkheologii: ucheniia, shkoly i lichnosti v 2-kh tomakh [History of Russian archaeology: teachings, schools and personalities in 2 vols.]. Saint Petersburg, Evraziia, 704 p., $640 \mathrm{p}$.

Lebedev, G.S. (1992). Istoriya otechestvennoj arheologii. 1700-1917 gg. [History of Russian archeology. 1700-1917]. Saint Petersburg, SPbGU, 464 p.

Matiushchenko, V.I. (2001). Trista let istorii sibirskoi arkheologii v 2-kh tomakh [Three hundred years of the history of Siberian archaeology in 2 vols.]. Omsk, OmGU, 178 p., 173 p. 
Petri, B.E. (1923a). Sibirskii paleolit [Siberian Paleolithic]. Irkutsk, 47 p.

Petri, B.E. (1923b). Programma issledovaniia stoianok pod otkrytym nebom [The program of research of sites in the open air]. Irkutsk, $15 \mathrm{p}$.

Petri, B.E. (1926). Sibirskii neolit [Siberian Neolithic]. Irkutsk, 39 p.

Petri, B.E. (1928). Dalekoe proshloe Pribaikal'ia [The distant past of the Baikal region]. Irkutsk, Izdatel'stvo Vlast' Truda, 1928, 73 p.

Platonova, N.I. (2010). Istoriia arkheologicheskoi mysli v Rossii. Vtoraia polovina XIX-pervaia tret' $X X$ veka [The history of archaeological thought in Russia. The second half of the XIX-the first third of the $X X$ century]. Saint Petersburg, Nestor-Istoriia, $316 \mathrm{p}$.

Radlov, V.V. (1989). Iz Sibiri [From Siberia]. Moscow, Nauka, 749 p.

Teploukhov, S.A. (1927). Drevnie pogrebeniia v Minusinskom krae [Ancient burials in Minusinsk region]. In Materialy po etnografii, 3, 2, 57-112.

Teploukhov, S.A. (1929). Opyt klassifikatsii drevnikh metallicheskikh kul'tur Minusinskogo kraia [An experience in classification of ancient metal cultures of Minusinsk region]. In Materialy po etnografii, $4,2,41-62$.

Tikhonov, I.L. (2003). Arkheologiia v Sankt-Peterburgskom universitete: Istoriograficheskie ocherki [Archaeology at St. Petersburg University: Historiographic essays]. Saint Petersburg, Izdatel'stvo S.-Peterburgskogo universiteta, $332 \mathrm{p}$.

Tunkina, I.V. (2002). Russkaia nauka o klassicheskikh drevnostiakh inga Rossii (XVIII-seredina XIX v.) [Russian science on classical antiquities of the south of Russia (XVIII-mid XIX c.)]. Saint Petersburg, Nauka, 676 p.

Formozov, A.A. (1961). Ocherki po istorii russkoi arkheologii [Essays on the history of Russian archaeology]. Moscow, Izdatel'stvo AN SSSR, 128 p.

Formozov, A.A. (1986). Stranitsy istorii russkoi arkheologii [Chapters of the history of Russian archaeology]. Moscow, Nauka, $240 \mathrm{p}$.

Formozov, A.A. (1995). Russkie arkheologi do i posle revoliutsii [Russian archaeologists before and after the revolution]. Moscow, IA RAN, $144 \mathrm{p}$.

Khaminov, D.V. (2011). Istoricheskoe obrazovanie i nauka v Tomskom universitete v kontse XIXnachale XXI v. [Historical education and science at Tomsk University in the late XIX-the early XXI c.]. Tomsk, Izdatel'stvo Tomskogo universiteta, 270 p. 


\title{
Археологическая наука и образование \\ в сибирских университетах на переломе эпох
}

\author{
Л.Ю. Китова \\ Кемеровский государственный университет \\ Российская Федераиия, Кемерово
}

\begin{abstract}
Аннотация. Предметом проведенного исследования стала археологическая наука и образование в Сибири в конце XIX - первой трети XX в. Цель статьи - анализ развития сибирской археологии на переломе эпох, когда в регионе впервые появляются профессионалы высокого уровня, бежавшие от большевиков из европейской части России и эвакуированные А.В. Колчаком из Казанского и Пермского университетов. Были установлены причины активизации археологической деятельности в Сибири в 1918-1926 гг., воссоздана целостная картина ее развития. Особое внимание уделяется выявлению специфики процесса подготовки исследователей древностей в Томском и Иркутском университетах. Если в Томском университете по инициативе профессора С.И. Руденко и преподавателя С. А. Теплоухова велась индивидуальная подготовка палеоэтнологов в рамках естественнонаучного цикла дисциплин, то в Иркутском университете была создана первая в Сибири археологическая школа. Модернизация высшего образования в первые годы советской власти привела к уничтожению в сибирских университетах недавно появившегося исторического образования и прекращению подготовки археологов.
\end{abstract}

Ключевые слова: археология, подготовка историков, Томский университет, Иркутский университет, палеоэтнологическая научная школа.

Научная специальность: 07.00.00 — исторические науки и археология. 